\title{
Processes of Value Co-creation at a Tourist Accommodation
}

\author{
DOI: 10.12776/QIP.V22I3.1158
}

\author{
Anette Oxenswardh \\ Received: 09 September 2018 Accepted: 06 November 2018 Published: 30 November 2018
}

\begin{abstract}
Purpose: This paper aims to study how a pair of hosts for one bed and breakfast establishment and their guests create value for the visit by communicating and interacting with each other on the island of Gotland.

Methodology/Approach: A case study was conducted on one single Bed and Breakfast $(\mathrm{BnB})$ accommodation. An interview and a Questionnaire study were performed.
\end{abstract}

Findings: The study shows that there are several processes involved in the cocreation of values between visitors and hosts. Co-creation processes begin already when visitors are planning their visits to the island. Their expectations are created while choosing their accommodation type, often done online on different websites. Pre-information about the chosen $\mathrm{BnB}$ accommodation contributes to visitors' expectations and image of the object, which can be seen as a part of their identities. In the physical meeting with the accommodation and the hosts and other guests, the co-creation process is strengthened. There are processes of participation, communication, creation of meaning for the stay, processes of trust and responsibilities which all together create a common culture which in turn contributes to co-creation of values for both parties. These processes also take place between guests. The processes are furthermore dependent on meaning-making and sensemaking processes. This all together generate knowledge about the destination and the values that enhance the positive experience of the visits. It also creates knowledge for the hosts about how they can develop their service to achieve increased customer satisfaction. Finally, these skills can be valuable for the continued planning and development of the tourism industry.

Research Limitation/implication: The study is limited to a one single BnB accommodation with its hosts on the island of Gotland in Sweden. 
Originality/Value of paper: The study makes a contribution to the knowledge of processes of co-creation values by exploring how some visitors and their hosts experienced visits to the island. The study can help bridging the gap in the views and actions on co-creation of values among visitors and those who are visited.

Category: Research Paper

Keywords: $\mathrm{BnB}$ accommodation; experiences; processes of value co-creation; sensemaking

\section{INTRODUCTION}

Tourism is today one of World's and also Sweden's most promising industries. The tourism industry on the island of Gotland has been an important economic factor for more than 150 years (Tillväxtverket, 2016). The biggest challenge for tourism in the future is to achieve local sustainable development (Byrd, Cárdenas and Greenwood, 2008). The concept of the experience economy states that as services become increasingly commoditized, companies must look to differentiate their offerings by focusing on the design and delivery of experiences (Pine and Gilmore, 1998). Experiences indicate the next step in the progression of economic value, requiring businesses to shift from a delivery-focused service paradigm to one that recognizes that the service is simply the arena to engage individual customers in a personal way (Walls et al., 2011).

In a hospitality and tourism setting, according to Oh, Fiore and Jeoung (2007), can everything tourists go through at a destination become an experience: being it behavioural or perceptual, cognitive or emotional, or expressed or implied experiences (Oh, Fiore and Jeoung, 2007). Visitors play an active, co-creative role in determining and constituting value-in-use through resource inputs in their experiences in destinations (Prebensen, Vitters $\varnothing$ and Dahl, 2013). In the industry, experience-related research is well presented but remains still underrepresented in the area of hospitality and tourism research (Ritchie, Wing Sun Tung and Ritchie, 2011).

In the shift towards sharing and collaborative consumption has caused notable implications for the accommodations industry. Probably the most famous organizer of private run bed and breakfast providers is Airbnb, grounded 2008. The organization has faced several and severe resistance from the established accommodation industry. Nevertheless, they have managed to become one of the largest organizers for private accommodation booking platforms online for tourists around the world. (Barnes and Mattsson, 2016). The number of other Bed and Breakfast $(\mathrm{BnB})$ accommodations are today increasing and also very popular among travellers visiting the island of Gotland in Sweden. They are usually small family owned BnBs with only a few rooms for renting. The tourist season on the island is concentrated mostly to the summer months, June, July and August. 
Bed and breakfast accommodations are not merely a conventional medium for the exchange of hospitality products (Katz, 2015) but serves as a stage for sociocultural exchange. In contrast to tourists staying in the traditional accommodation sector, $\mathrm{BnB}$ accommodations offer a window into local experiences, in which guests can extend their footprint by immersing themselves and discovering the local community (Fang, Ye and Law, 2016).

Accommodations can symbolize more than the traditional sharing of a space (Barnes and Mattsson, 2016) and fosters the sharing of a local social place (Tussyadiah and Pesonen, 2016). While studies into experience and value cocreation have received much attention in recent tourism and hospitality studies (Morosan and DeFranco, 2016; Neuhofer, Buhalis and Ladkin, 2012; Shaw, Bailey and Williams, 2011), there is still a gap in understanding how experiences and values are created in collaborative marketplaces, such as Airbnb, and the wider sharing economy (Yannopoulou, Moufahim and Bian, 2013).

Wilson and Harris (2006) point out, that meaningful travel involves the search for an increased sense of self and reconsideration of perspectives on life, society and relationships with others. It is also emphasized by Boswijk, Thijssen and Peelen (2007) that the dynamic nature of meaningful experiences can lead to personal insight for customers.

With reference to the aspects discussed above this paper aims to study how one bed and breakfast provider and their guests experience the processes of cocreation of values and sensemaking while socializing and communicating with each other. This particular accommodation is family owned establishment using Airbnb's booking and service system.

In order to be able to describe these processes, the model of sensemaking by Weick is used as a theoretical as well as a methodological foundation for the study.

\section{THEORETICAL ASPECTS OF THE STUDY}

\subsection{Consumers as Co-Creators}

Co-creation is described in the experience economy as an environment, in which the supplier constructs context and the consumer is part of it (e.g. Disneyland). Bendapudi and Leone (2003) argue that the co-production may extend even further and is not only about customers' involvement and participation in a physical sense but may also include psychological aspects.

Based on the S-D logic, service-dominant logic of marketing, customers and firms co-create value through an integration of a set of resources (Vargo, Maglio and Akaka, 2008). The findings of Agrawal and Rahman (2016), reveal the presence of three primary resources that form the basis of collaborative value cocreation efforts in bed and breakfast settings, namely, BnB home, places in the 
local community and the host as a distinct value creating actor. While the BnB home and places in the local community can be conceptualized as physical operand resources, the host emerges as a distinct operant resource (skills and knowledge) and a key resource integrator who, outside tourist zones, creates the basis upon which social practices and value co-creation can occur (Saarijarvi, Kannan and Kuusela, 2013). But how does this co-creation of values emerge in practice, individually and in collective meaning? These are questions that will now be investigated in the following sections.

\subsection{Meaningmaking and Sensemaking}

Meaning-making as a concept is described in psychology, as a process of through which people construe, understand, or make sense of life events, relationships, and the self (Ignelzi, 2000). Through meaning-making, persons are retaining, reaffirming, revising, or replacing elements of their orienting system to develop more nuanced, complex and useful systems (e.g. Gillies, Neimeyer and Milman, 2014).

The term is widely used in constructivist approaches. (e.g. Dorpat and Miller, 1992). The term is also used in educational psychology (Ignelzi, 2000; Mortimer and Scott, 2003).

Sensemaking, again, has been described as a process by which we give meaning to our collective experiences. It is often formally defined as the ongoing retrospective development of plausible images that rationalizes what people are doing (Weick, Sutcliffe and Obstfiel, 2005). The concept was introduced to organizational studies by Karl E. Weick in the 1970s and has since had an impact on both theory and practice. The concept was intended to favour a shift away from the traditional focus of organization theorists on decisionmaking and aiming towards the processes that constitute the meaning of the decisions that are enacted in behaviour. Research on sensemaking has become an important issue in organizational studies and has been growing as more researchers seek answers to how meanings are created in organizations (Hernes and Maitlis, 2013; Cornelissen, 2012; Monin et al., 2013).

Although Karl Weick is undeniably regarded as the founding father of sensemaking, his thoughts on organizational significance have been developed theoretically in different directions in the $21^{\text {st }}$ century. The current post-Weick sensemaking research field is considered fragmented (Brown, Colville and Pye, 2014). The position of sensemaking research in science is controversial today. Maitlis and Christianson (2014), also, Brown, Colville and Pye (2014), argue that there is no single sensemaking thinking, but several different views. Some researchers consider it a theory of sensemaking theory (e.g. Skålén and Strandvik 2005).

Other scientists talk about sensemaking lenses (e.g. Maitlis and Sonenshein, 2010; Colville, Pye and Carter, 2013). The sensemaking perspective approach is also used in sensemaking literature (e.g. Shahzad and Muller, 2016). 
Weick identified seven properties of sensemaking (Weick, 1995): Identity and identification are central. Who people think they are in their context shapes what they enact and how they interpret events (Pratt, 2000; Currie and Brown, 2003; Thurlow and Helms Mills, 2009). Retrospection ${ }^{1}$ offers the opportunity for sensemaking. The point of retrospection in time affects what people notice (Dunford and Jones, 2000), thus attention and interruptions to that attention are highly relevant to the process. A recent study, however, shows that sensemaking can be time-oriented for both the past, present and future (e.g. Gephart, Topal and Zhang, 2010).

Gephart, Topal and Zhang (2010) state that perceptions of the future are always based on the present and the past, and thus future-oriented thinking does not reject retrospectives. Gephart, Topal and Zhang (2010) have raised an ethnomethodological approach to sensemaking's timely question. According to the thought, the sensemaking takes place in size and does not have a temporal beginning or end. Thus, the temporal nature and location of the sensemaking cannot be shown. (Maitlis and Christianson, 2014). People enact the environments they face in dialogues and narratives (Bruner, 1991; Currie and Brown, 2003). While speaking, people build narrative accounts which are helping them to understand what they think and organize their experiences as well as control and predict events (Isabella, 1990; Weick, 1995; Abolafia, 2010) and reduce complexity in the context of change management. Sensemaking is a social activity in that plausible stories are preserved, retained or shared (Isabella, 1990; Maitlis, 2005). However, the audience for sensemaking includes the speakers themselves (Watson, 1995). The narratives are both individual and shared, an evolving product of conversations with ourselves and with others (Currie and Brown, 2003). Sensemaking is ongoing by individuals simultaneously shaping and reacting to the environments they face.

People learn about their identities by projecting themselves onto this environment and observing the consequences and the accuracy of their accounts of the world (Thurlow and Helms Mills, 2009). This is a feedback process so even as individuals deduce their identity from the behaviour of others towards themselves, they also try to influence this behaviour.

As Weick argued, the basic idea of sensemaking is that reality is an ongoing accomplishment that emerges from efforts to create order and make retrospective sense of what occurs (Weick, 1993). People extract cues from the context to help them decide on what information is relevant and what explanations are acceptable (Salancick and Pfeffer, 1978; Brown, Stacey and Nandhakumar, 2007). Extracted cues sort out points of reference for linking ideas to broader networks of meaning. They are simple, familiar structures that are fragments from which people create a larger understanding of what may be occurring

\footnotetext{
${ }^{1}$ Identity can be understood through multiple frames of reference. The core idea in the different definitions is: "Identity is what construes a person, that is, who I am, to which I belong. It contains the essence of being self, which separates me from others" (Gioia, 1998, pp. 19).
} 
(Weick, 1995). People favour plausibility over accuracy in descriptions of events and contexts (Abolafia, 2010).

An obsession with accuracy seems fruitless and impractical among people with multiple shifting identities in shaping their world, according to Weick (1995).

The research on sensemaking in this study can be seen as procedural. Many post "weckian" theorists such as Cornelissen (2012), Hernes and Maitlis (2013), Gephart, Topal and Zhang (2010), and Maitlis and Christianson (2014) emphasize the processuality of sensemaking and diverse art of the process. The process is dynamic, active and continuous (e.g. Gephart, Topal and Zhang, 2010). Another factor contributing to this study is the social nature of the process hosts interacting with their guests. According to Weick (1995), sensemaking takes place in interaction with the members of the organization, but also intersubjectively. Collectively shared meanings, build on such an organization a reality that enables members of the community to function in a meaningful way (e.g. Gephart, Topal and Zhang, 2013; Hernes and Maitlis, 2013; Maitlis and Christianson, 2014). Among others, Cornelissen (2012) and Maitlis and Christianson (2014), emphasize the significance of the environment in the sensemaking process.

According to the Weick (1995), there are three stages of the sensemaking process. The first step of the sensemaking process consists of three stages: noticing, bracketing and creating an initial sense. In this phase, existing information is screened and explanations are searched for an event that interferes with the activities of the members of the organization. Hinting, becoming conscious, and brainstorming can only take place on the individual existing informational frameworks, i.e. mental models, which in turn are based on previous experiences (Weick, Sutcliffe and Obstfeld, 2005). Creating an initial sense is done through categorization. Weick and his partners use the term labelling.

The labelling phase is looking for credible explanations for what happened. Phase two includes the interpretation of clues, the formation of intersubjective meanings, and the construction of a cognitive map.

Action is an essential part of the sensemaking process. Weick (1995) asks in his book, Sensemaking in Organizations, an important question: How does the action become coordinated in the world of multiple realities? Weick's answer is through communicative interaction. Brown, Stacey and Nandhakumar (2007) suggest that organizational activities are coordinated with narrative structures as they create the organization and its social reality. Weick states that activity generates raw material for sensemaking. It also creates the hints and stimuli needed to start the process, which in turn reinforces the process. This is important because it tests the understanding and gives feedback on the understanding that is generated in the process, and at the same time, it creates the basis for new meaningfulness. Thus, activity and cognition belong together (Weick, 1988). 
These theoretical aspects, presented above, are used in this study as a foundation for analysing and understanding the processes involved in the interaction between guests and hosts at the $\mathrm{BnB}$ accommodation. Both meaning making and sensemaking is to be seen as processes involved within the interaction between guests and hosts, in this study, at the BnB accommodation.

\section{METHODOLOGY AND DEMARCATIONS}

In this study, a process-oriented perspective is used. Sensemaking and cocreation processes are closely related to one another (Hernes and Maitlis, 2013). However, the process is an ambivalent term. It can be understood either in organizations as visible artefacts, such as language, meaning, social interaction or power-related relationships, or it can be understood ontologically as an expression of reality (Chia, 2010).

From the point of view of the artefacts, the process can also be seen as a series of activities in which members of the organization are seeking understanding of unclear and confusing events in the operating environment. Sensemaking can be seen as a non-linear process. It does not happen in certain periods, but the process functions overlap and their intensity varies. The process is different for each member of the organization (Thurlow and Helms Mills, 2009).

This study is of qualitative and explorative art (Yin, 1994) and was performed as a case study in one single bed and breakfast accommodation. An interview and questionnaire study were conducted. The questionnaire was digitally sent to some 50 visitors or couples and their 2 hosts after their visits.

The respondents consisted of 46 couples who got interviewed at the accommodation and two hosts. The questionnaires were send them digitally after their visit and can even be seen as an evaluation of the experiences of the visit. Both interviews and questionnaires followed the same type of design. This design, in turn, followed and was inspired of Weick's seven properties of sensemaking.

Demarcations of the study are that it consists only one bed and breakfast accommodation and their guests and hosts. In this study sensemaking is seen as both cognitive and constructive approach.

The analysis of the processes in the study follows the theoretical framework of sensemaking and co-creation of values. The involved processes, supporting processes (encounters) as well as main process, are to be seen as interconnected. The sensemaking process has certain features. The seven qualities of the process, according to Weick (1995), are used as analyse criteria as well as the logic of three phases or stages of the sensemaking process: a) awakening, b) interpretation, building intersubjective meanings and creating a cognitive map, and c) action. The thematic analysis of processes resulted in the emergence of 
distinct themes of social practices, practice elements and value formations, which are presented in the findings in next section.

\section{RESULTS - REVEALING A PROCESS-BASED FRAMEWORK}

The selected data shows several processes involved in the meeting of hosts and guests while planning, meeting, discussing and participating in the social construction of accommodating on one single bed and breakfast establishment. The study revealed both support processes and main processes. In the following sections, these processes are presented in short with some respondent statements and figures over the results.

\subsection{Encounters}

In the following, encounter processes of value-co-creation are presented with a help of the Fig. 1. Encounters. Some statements from the respondents on each encounter are presented. Both parties in the co-creation process, hosts and guests, and their perspectives are explored and discussed in this study. Encounters can be seen as the processes that seem to be leading to co-creation of values for both hosts, in taking care of and offering accommodation for the guests; as well as to the guests, who are staying in bed and breakfast accommodation. Encounter processes are the processes and practices of interaction and exchange that take place between hosts and guests within social interaction.

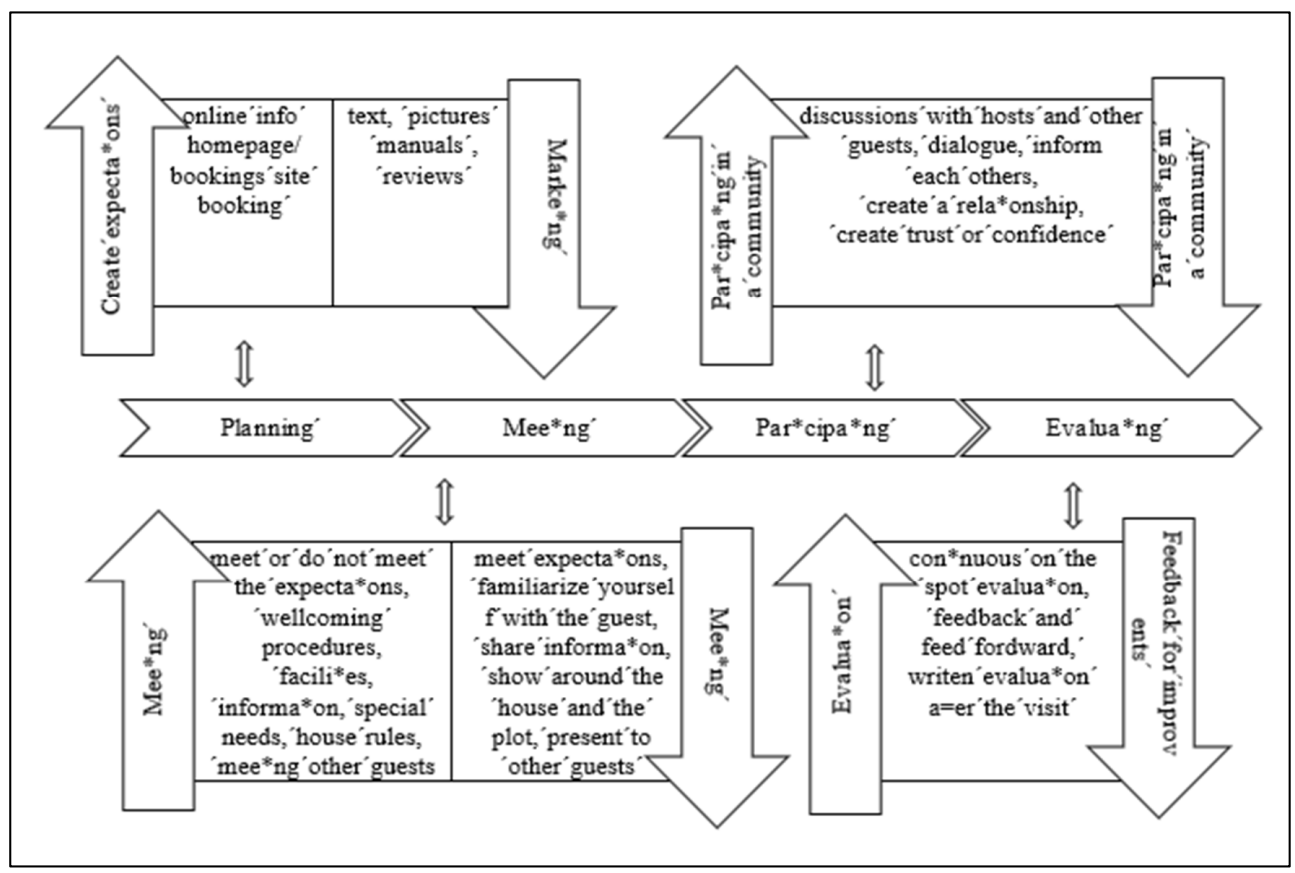

Figure 1 - Encounters 


\subsection{Planning - to Create Expectations}

There were different reasons to visit the island among visitors. Some of them, mostly foreign visitors, had heard or had read about the island in some guidebooks, such as Lonely Planet. Others had got hints from their friends who already had visited the island. Many of couples mentioned that it was to seek some tranquillity and nature experiences as a contrast to city tourism when making their choice of visiting the island and this specific accommodation. The information offered about the island in advance was accurate and corresponded quite well the experiences visitors had of the island. Furthermore, the couple's expectations were well corresponding with their experiences of the visit: Service, at the restaurants, tours, museums etc. organized and offered for the visitors, was in general experienced as very satisfactory:

Generally good, but Visby is too touristic and stressful, some of the younger waiters and service people were less service minded.

The attractions on the island received also good reviews from the visitors. There were couples that wished some more bicycle lanes, though. One couple was pleased with the number of different attractions on such a limited area.

The first thing visitors do in order to start their processes of visiting the resort is to plan their trip. Usually to book the tickets for the trip and then book the accommodations needed. As it seems to be the case today, it's often alternative forms of accommodations which are preferred while people are travelling.

In order to plan the trip, visitors use online services consisting of homepages and booking sites. While planning their stay visitors look the different and wide spectra of offering accommodation possibilities on Gotland. Already here, at the start, they do begin the process of creating values for the whole trip. By sorting the object, they really select something due to the different parameters after their needs, expectations and economical resources. Below some statements presented from the guests.

We are so happy; our room was exactly like in the pictures.

But not all of the couples were as satisfied:

The nature is such wonderful but the town Visby did not met our expectations.

Hosts, in turn, offers symbols for visitors' selections by designing their homepages and booking sites with pictures and images, creating expectations or disexpectations. Information, text and pictures are short advertisements over eventually upcoming accommodation. These can both attract or deter the customer. This process can be seen as a part of marketing.

\subsection{Meeting}

In the physical meeting, visitors confirm or must reject their expectations. This is a multi-level meeting: The guests can experience the house as it turns out in 
reality by meeting their hosts, by familiarizing with the room and the rest of the house and it's surroundings. They also get acquainted with other guests. Information exchange about house rules do take place; preliminary information about the surroundings, local history, nearest grocery store, restaurants and public transportation are issues discussed within this first contact.

The BnB providers meet the guests with their different questions and give some standardized information on the house and surroundings. This physical meeting enables both parties to confirm their expectations.

The host can also have the first opportunity to evaluate the guest's satisfaction with the room and the facility. Hosts can also discover guests' special requests, plans for the nearest days and excursions.

The first experience of the house was very bad. We didn't get the room we had hoped for.

\subsection{Participation - Creating Relationship}

While the guests have installed themselves in the house, a process of participation in the daily life of the house begins, participation in the Community, its' people and routines. Not every guest wishes to participate the community. Some of them, though, are limiting their social participation to the curtesy against hosts and other guests and prefer withdrawing from the community. But it's more common among the BnB guests being active and willing to participate in the company of others, according to the hosts. To participate means, in this study, that hosts and guests find occasions to discuss different matters with each other's in order to create a relationship by dialogue. Such occasions are offered around breakfast time, within other meals and within other kinds of unscheduled meetings in the house or in the garden. In these discussions, different issues are reasoned and dealt with. The guests are telling about their experiences from their daytrips consisting many different activities. The host are giving their local picture of matters and dealing hints and advices over the visiting objects. All in all, they are learning from each other's and can create value to their visit in this way. While changing their experiences they are creating relationship built on trust and confidence into each other's.

During the breakfast, we talked to the hosts and other guests about our plans on the trip, our lives back home, our children, matters of sustainability etc.

\subsection{Evaluation}

Evaluating is an ongoing process between the guests and the hosts. This process does already start while planning the trip and planning to welcome the guests. It continues at arrival by guests contrasting their expectations with the physical environment and the accommodation itself, the hosts and the other guests. This evaluation takes place throughout the trip and the stay on the accommodation as well as after the visit in the form of an evaluation carried out digitally in this BnB 
accommodation. The same process is being reviewed by the hosts. In these surveys, the guests are pointing out values being added to their stay by taking up issues like comfort, space, cleanliness, resources and amenities they could share at $\mathrm{BnB}$ home. Such as Wi-Fi, kitchen facilities, coffee machine etc. Also, ability to cook their meals, ability to buy the meals, ability to share and spent time in the garden with the hosts and other guests were mentioned as a value-creating issues. Socializing with other guests were mentioned as something positive and valuable. Staying with their own pet on the accommodation were also reported as a value-adding dimension.

We were having interesting discussions with our hosts and co-guests about water shortage and other issues of sustainability on the island.

To sum up the presentation of encounters above, they can also be understood and explained through the three phases of sensemaking process expressed by Weick (1995). Namely awakening, interpretation, building intersubjective meanings and creating a cognitive map, and action. In the following the sensemaking process with the seven known and thought-based qualities of the process by Weick, the features are analysed.

\subsection{Analysing Properties of Sensemaking}

Sensemaking is grounded in identity construction. Weick identified seven properties of sensemaking (Weick, 1995). Identity and identification is central who people think they are in their context shapes what they enact and how they interpret events (Currie and Brown, 2003; Weick, Sutcliffe and Obstfeld, 2005; Thurlow and Helms Mills, 2009). An individual understands the matter or the phenomenon only when he has spoken up her thoughts. An individual does not form her identity in a vacuum, but it is shaped by social relations (Weick, 1995). An individual learns to understand who she really is by looking upon herself through others. Based on the empirical evidence of this study, the choice of holiday is made, to a certain extent, to strengthen the self-image of the visitors. Destinations, accommodation, excursion goals, etc. are chosen to reflect the selfimage, consciously or unconsciously.

The house was full of antiques and travel memories from around the world. It created a harmony for our stay.

To summarize this section, it can be argued that there seems to be a connection between the chosen type of accommodation and visitors' self-image or part of identity. Yet, there is a connection between the hosts' way of designing their home, the $\mathrm{BnB}$ accommodation, and their identity.

\subsection{Sensemaking Based on A Review of The Past}

By looking retrospectively backwards, people learn through their experiences and can move their learning into future activities (Weick 1995; Weick, Sutcliffe and Obstfeld, 2005). This can still be time-oriented for both the past, present and 
future according to some researchers (e.g. Gephart, Topal and Zhang, 2010). Because our perceptions of the future are always based on the present and the past. According to these ideas, the sensemaking takes place and does not have a temporal beginning or end. Guests tell about their experiences regarding visitor destinations, service etc. and compare their past experiences to today's experiences. But they also make suggestions for improvement on various issues they have experienced.

Routes for walking and biking have to be improved. $\square$ At the same time, Visby it's also clearly getting swamped every summer with thousands of people.

\subsection{Enactment}

Sensemaking shows the mutual sensitivity of cognition and activity to the environment. Sensemaking is the synthesis of cognition and activity (Weick, 1995). Weick (1988, 1995; Weick, Sutcliffe and Obstfeld, 2005) refers to the word enactment, which means the involvement of people in the creation of their environment. The guests are discussing with each other's and with the hosts during the different occasion of their visits. These discussions varies all from places to visit, environmental sustainability issues on the island, politics and private family matters.

Our hosts discuss with us all kind of matters and gave us valuable advices on life, divorces, sustainability etc.

\subsection{Sensemaking is Social}

The process of sensemaking is basically social. It's going on in interaction with the various guests of the accommodation. The social nature of sensemaking becomes visible when guests of the accommodation interpret their environment in interaction with other guests and construct explanations that help them to understand the reality and to act collectively (Weick, Sutcliffe and Obstfeld, 2005). Creation of meaningfulness requires shared meanings (Weick, 1995).

Due the visitors' statements, they share same kind of experiences with other guests by visiting often same attractions. This, in turn, gives possibilities to talk over more profound about what they have been experiencing during the visits.

\subsection{Hints as Triggers}

The hints (extract cues) from the environment seem to fit well with the previously experienced experiences of the guests. They can interpret them even though the things' ambiguous nature. Guests filters also all the time the flow of information around them and chooses pieces fitting into their own structure of significance. In discussions at the $\mathrm{BnB}$ some hints (e.g. where to go, what to see) are highlighted, and on the other hand, some others never come into focus.

Some other guests at the BnB told us about the nice pottery, which we then 
visited.

\subsection{Sensemaking as an Ongoing Process}

When guests at the accommodation react to the environment and shape it with the help of cognition and social actions, one can talk about the continuing nature of sensemaking. Sensemaking has then neither the beginning nor the end because meaningfulness takes place at all time in the continuous flow of events (Weick, 1995). Guests always try to understand what is happening around them. This shows how guests and hosts take part in this process already in initial phases: planning the trip as a guest or marketing the establishment as a host.

\subsection{Sensemaking Based More on Plausibility than on Accuracy}

Continuous change in information flow makes accuracy meaningless for the guests. In order to be able to transform information into their own understanding, there is a need of plausible explanations. These can be other guests' and hosts' subjective experiences as well as guidebook texts and other informants. This information has to bee then inserted with their own and earlier experiences, in order to make sense. Sensemaking is both individual and collective activity (Weick, 1995). It is an individual and collective process simultaneously. Above it has been described how Karl Weick constructs the nature of the sensemaking process based on seven characteristics. According to Weick (1995), they define the sensemaking process and make it possible to understand why any situation, activity or phenomenon is shaped as it is formed and why people give different meanings to the same thing. Research literature utilizes the features of the sensemaking process created by Weick, although the evidence of the appearance of properties and the relationships between them is rather limited. Probst (2012) and Lunkka, Suhonen and Turkki (2015) have shown that the seven determinants of the Weick's sensemaking process are still useful and also relevant.

\section{CONCLUSIONS}

This research aimed to create new knowledge about the processes involved in the co-creation of values between providers and their guests at one single BnB accommodation on the island of Gotland in Sweden. The interplay between these two actors can be seen as a platform or arena for value-creation. The stay and the interaction with the hosts do not only create value for the accommodating itself but also for whole trip for the visitors. The hosts can be seen as co-producers of values. This value-creation process includes several other processes, so-called encounters.

In this study, the encounters are to be seen as supporting processes to the main process of co-creation of values. With the help of these supporting processes both parties create meaning for the visits. Sensemaking is a collective process which seem to take place simultaneously with individual process of meaning-making. 
In this study, the focus has been on sensemaking as a process which gives meaning to our collective experiences. In order to understand the process of cocreating values, this study has used Weick's seven determinants for sensemaking. With the help of the figure below, Fig. 2, the process of co-creation of values is described.

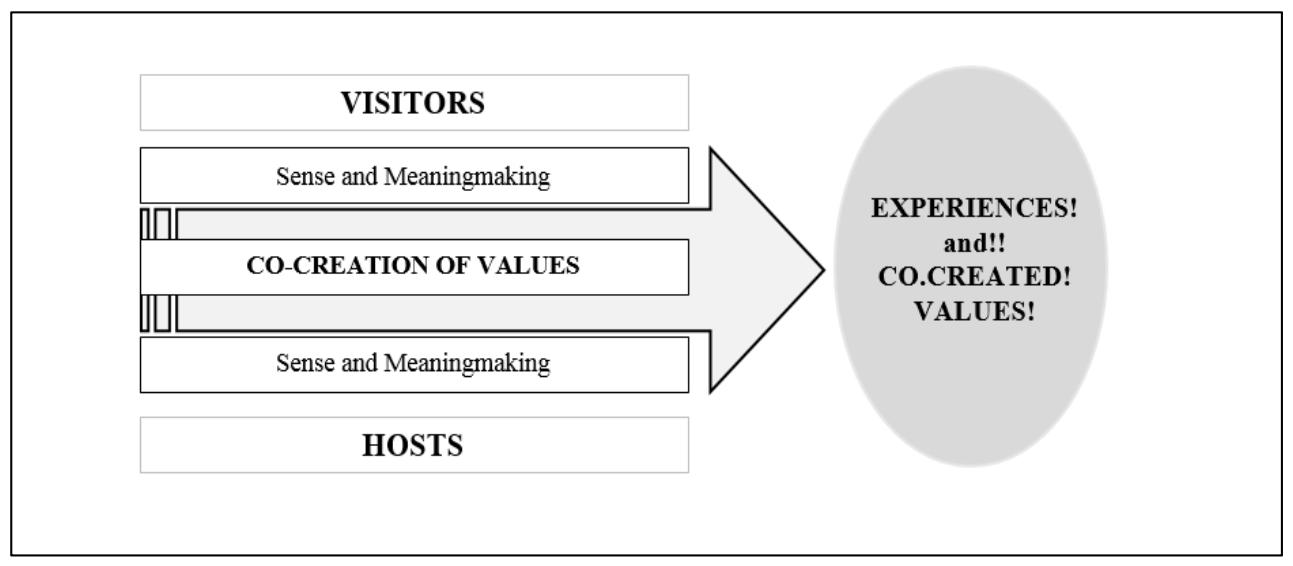

Figure 2 - Process of Co-creation of Values

Co-creation of values can be comprehended as both individual and social construction of values. Encounters can be regarded as supporting processes within the main process of value creation. Value-creation is an ongoing process from planning the trip to evaluation of it. This process is procedural, but it is not necessarily linear. Encounters or supporting processes can be described as phases or arenas to create interaction between the actors. On these arenas, the guests create values through sensemaking processes for the whole journey. Then BnB accommodation can be seen as generator for this process. This type of accommodating hospitality gives guests easier possibilities to share their experiences with the hosts and other guests. The hosts, in turn, get immediate confirmation or feedback on their recommendations. This helps the host to develop their business and sharpen their advice on local attractions. Social interaction between guests and hosts creates comfort and homeliness. Discussion with other guests and hosts are more informal for their character. This can be compared against the more formal knowledge in guidebooks and brochures.

The process of co-creation seems to be an important part of our identity and it strengthens it in many ways. Guests are looking for accommodations that fit into their identity, which they consider themselves to represent. Choosing a small, family-run $\mathrm{BnB}$ rather than a large hotel allows one to be both seen and acknowledged as a person. This enables for some kind of revision of the selfimage. This, in turn, creates value for the trip. Choosing to stay on a BnB has become more and more common among visitors worldwide. It is therefore important to create knowledge about how this type of accommodation creates value for visitors. Staying at the $\mathrm{BnB}$ seems to be a more complex social 
environment than staying at the hotel. This creates greater demands on both hosts and guests. Requirements for social interaction increased knowledge of the local community, it's culture, sights, history, activities and, not least, issues of sustainable tourism. This is, if possible, even more, important knowledge for visit organizers, accommodation suppliers and hosts. Maybe it is important to provide training for the hosts; to enable them to be active players in the creation of sustainable local tourism through social construction.

\section{REFERENCES}

Abolafia, M.Y., 2010. Narrative Construction as Sensemaking: How a Central Bank Thinks. Organization Studies, 31(3), pp.349-367.

Agrawal, A.K. and Rahman, Z., 2016. Consequences of consumer participation in value co-creation. In: NIDA International Business Conference 2016, Proceedings of NIDA: International Business Conference 2016 Sustainability in Business. Conferences Proceedings. Bangkok, Thailand, 12 March 2016. Bangkok: NIDA Business School.

Barnes, S. and Mattsson, J., 2016. Understanding current and future issues in collaborative consumption: A four-stage Delphi study. Technological Forecasting \& Social Change, 104, pp.200-211. http://dx.doi.org/10.1016/j.techfore.2016.01.006.

Bendapudi, N. and Leone, R.P., 2003. Psychological Implications of Customer Participation in Co-Production. Journal of Marketing, 67(1), pp.14-28. http://dx.doi.org/10.1509/jmkg.67.1.14.18592.

Boswijk, A., Thijssen, T. and Peelen, E., 2007. Meaningful Experiences, The Experience Economy: A New Perspective. Amsterdam: Pearson Education Benelux.

Brown, A.D., Colville, I. and Pye, A., 2014. Making sense of in organization studies. Organization Studies, $36(2), \quad$ pp.265-277. https://doi.org/10.1177/0170840614559259.

Brown, A.D., Stacey, P. and Nandhakumar, J., 2007. Making sense of narratives. Human Relations, 61(8), pp.1035-1062.

Bruner, J., 1991. The narrative construction of reality. Critical Inquiry, 18(1), pp.1-21.

Byrd, E.T., Cárdenas, D.A. and Greenwood, J.B., 2008. Factors of stakeholder understanding of tourism: The case of Eastern North Carolina. Tourism and Hospitality Research, 8(3), pp.192-204. http://dx.doi.org/10.1057/thr.2008.21.

Chia, R., 2010. Rediscovering Becoming: Insights from an Oriental Perspective on Process Organization Studies. In: T. Hernes and S. Maitlis, eds. 2010. Process, sensemaking, and organizing. Oxford: Oxford University Press. Ch. 7. 
Colville, I., Pye, A. and Carter, M., 2013. Organizing to counter terrorism: Sensemaking amidst dynamic complexity. Human Relations, 66(9), pp.12011223. http://dx.doi.org/10.1177/0018726712468912.

Cornelissen, J.P., 2012. Sensemaking under pressure: the influence of professional roles and social accountability on the creation of sense. Organization Science, 23(1), pp.118-137. http://dx.doi.org/10.1287/orsc.1100.0640.

Currie, G. and Brown, A., 2003. A narratological approach to understanding processes of organizing in a UK hospital. Human Relations, 56(5), pp.563-586. https://doi.org/10.1177/0018726703056005003.

Dorpat, T.L. and Miller, M.L., 1992. Clinical interaction and the analysis of meaning: a new psychoanalytic theory. Hillsdale, NJ: Analytic Press.

Dunford, R. and Jones, D., 2000. Narrative in strategic change. Human Relations, 53(9), pp.1207-1226. https://doi.org/10.1177/0018726700539005.

Fang, B., Ye, Q. and Law, R., 2016. Effect of sharing economy on tourism industry employment. Annals of Tourism Research, 57, pp.264-267. https://doi.org/10.1016/j.annals.2015.11.018.

Gephart, R.P., Topal, C. and Zhang, Z., 2010. Future-oriented Sensemaking: Temporalities and institutional legitimation. In: T. Hernes and S. Maitlis, eds. 2010. Process, sensemaking, and organizing. Oxford: Oxford University Press. Ch. 13.

Gillies, J., Neimeyer, R.A. and Milman, E., 2014. The Meaning of Loss Codebook: Construction of a System for Analyzing Meanings Made in Bereavement. Journal Death Studies, 38(1-5), pp.207-2016. https://doi.org/10.1080/07481187.2013.829367.

Gioia, D.A., 1998. From individual to Organizational Identity. In D.A. Whetten and P.C. Godfrey, eds. 1998. Identity in Organizations. Building Theory Through Conversations. Thousand Oaks, CA, US: Sage Publications. 17-31.

Hernes, T. and Maitlis, S., 2013. Process, sensemaking, and organizing. Oxford: Oxford University Press.

Ignelzi, M., 2000. Meaning-Making in the Learning and Teaching Process. New directions for teaching and learning, 2000(82), pp.5-14.

Isabella, L.A., 1990. Evolving interpretations as change unfolds: How managers construe key organisational events. Academy of Management Journal, 33(1), pp.7-41.

Katz, V., 2015. Regulating the sharing economy. Berkeley Technology Law Journal, 30(4), pp. 1067-1126. https://doi.org/10.15779/Z38HG45. 
Lunkka, N., Suhonen, M. and Turkki, L., 2015. Sairaalan projektit materialisoitumisen areenoina - ylihoitajien kokemuksia muutosprosesseista. Hallinnon Tutkimus, 3(34), pp.233-248.

Maitlis, S. and Christianson, M., 2014. Sensemaking in organizations: Taking stock and moving forward. The Academy of Management Annals, 8(1), pp.57125. https://doi.org/10.1080/19416520.2014.873177.

Maitlis, S. and Sonenshein, S., 2010. Sensemaking in crisis and change: Inspiration and insights from Weick (1988). Journal of Management Studies, 47(3), 551-580. https://doi.org/10.1111/j.1467-6486.2010.00908.x.

Maitlis, S., 2005. The social processes of organizational sense making. The Academy of Management Journal, 48(1), pp.21-49.

Monin, P., Noorderhaven, N., Vaara, E. and Kroon, D., 2013. Giving sense to and making sense of justice in postmerger integration. Academy of Management Journal, 56(1), pp.256-284. https://doi.org/10.5465/amj.2010.0727.

Morosan, C. and DeFranco, A., 2016. Co-creating value in hotels using mobile devices: a conceptual model with empirical validation. International Journal of Hospitality Management, 52, pp. 131-142.

Mortimer, E.F. and Scott, P.H., 2003. Meaning Making in Secondary Science Classrooms. Maidenhead, UK: McGraw-Hill Education.

Neuhofer, B., Buhalis, D. and Ladkin, A., 2012. Conceptualising technology enhanced destination experiences. Journal of Destination Marketing \& Management, 1(1-2), pp.36-46. https://doi.org/10.1016/j.jdmm.2012.08.001.

Oh, H., Fiore, A.M. and Jeoung, M., 2007. Measuring experience economy concepts: tourism applications. Journal of Travel Research, 46(2), pp.119-132. https://doi.org/10.1177/0047287507304039.

Pine, B.J. and Gilmore, J.H., 1998. Welcome to the experience economy. Harvard Business Review, 76(4), pp.97-105.

Pratt, M.G., 2000. The good, the bad, and the ambivalent: Managing identification among Amway distributors. Administrative Science Quarterly, 45(3), 456-493. https://doi.org/10.2307/2667106.

Prebensen, N.K., Vitters $\varnothing$, J. and Dahl, T.I., 2013. Value co-creation significance of tourist resources. Annals of Tourism Research, 42, pp.240-261. https://doi.org/10.1016/j.annals.2013.01.012.

Probst, M.M.P., 2012. Sensemaking during a complete process of revitalization in a complex context. Ph. D. University of Tilburg. Amsterdam: Empee Interim Management B.V.

Ritchie, J.R.B., Wing Sun Tung, V. and Ritchie, R.J.B., 2011. Tourism experience management research. International Journal of Contemporary Hospitality Management, 23(4), pp.419-438. 
Saarijarvi, H., Kannan, P.K. and Kuusela, H., 2013. Value co-creation: theoretical approaches and practical implications. European Business Review, 25(1), pp.6-19. https://doi.org/10.1108/09555341311287718.

Salancick, G. and Pfeffer, J., 1978. A social information processing approach to job attitudes and task design. Administrative Science Quarterly, 23(2), pp.224253.

Shahzad, K. and Muller, A.R., 2016. An integrative conceptualization of organizational com- passion and organizational justice: a sensemaking perspective. Business Ethics: An European Review, 25(2), pp.144-158. https://doi.org/10.1111/beer.12112.

Shaw, G., Bailey, A. and Williams, A., 2011. Aspects of service-dominant logic and its implications for tourism management: examples from the hotel industry. Tourism Management, 32(2), pp.207-214. https://doi.org/10.1016/j.tourman.2010.05.020.

Skålén, P. and Strandvik, T., 2005. From prescription to description: a critique and reorientation of service culture. Managing Service Quality, 15(3), pp.230244. https://doi.org/10.1108/09604520510597791.

Thurlow, A. and Helms Mills, J., 2009. Change, talk and sensemaking. Journal of Organizational Change Management, 22(5), pp.459-479. https://doi.org/10.1108/09534810910983442.

Tillväxtverket, 2016. Fakta om svensk turism. [pdf] Stockholm: Tillväxtverket. Available at: <http://publikationer.tillvaxtverket.se/ProductView.aspx?ID=2084> [Accessed 19 November 2018].

Tussyadiah, I. and Pesonen, J., 2016. Impacts of peer-to- peer accommodation use on travel patterns. Journal of Travel Research, 55(8), pp.1022-1040. https://doi.org/10.1177/0047287515608505.

Vargo, S., Maglio, P. and Akaka, M., 2008. On value and value co-creation: a service systems and service logic perspective. European Management Journal, 26(3), pp.145-152. https://doi.org/10.1016/j.emj.2008.04.003.

Walls, A.R., Okumus, F., Raymond, Y. and Kwun, D.J., 2011. An epistemological view of consumer experiences. International Journal of Hospitality Management, $\quad 30(1), \quad$ pp. 10-21. https://doi.org/10.1016/j.ijhm.2010.03.008.

Watson, T.J., 1995. Rhetoric, discourse and argument in organizational: A reflexive tale. Organization Studies, 16(5), pp.805-821. https://doi.org/10.1177/017084069501600503.

Weick, K., 1988. Enacted sensemaking in crisis situations. Journal of Management Studies, 25(4), pp.305-317. https://doi.org/10.1111/j.14676486.1988.tb00039.x. 
Weick, K., 1993. The collapse of sensemaking in organizations: The Mann Gulch disaster. Administrative Science Quarterly, 38(4), pp.628-652.

Weick, K., 1995. Sensemaking in Organisations. London: Sage Publications.

Weick, K., Sutcliffe, K.M. and Obstfeld, D., 2005. Organizing and the process of sensemaking. Organization $\quad$ Science, 16(4), pp.409-421. https://doi.org/10.1287/orsc.1050.0133.

Wilson, E. and Harris, C., 2006. Meaningful travel: women, independent travel and the search for self and meaning. Tourism, 54(2), pp.161-172.

Yannopoulou, N., Moufahim, M. and Bian, X., 2013. User-generated brands and social media: Couchsurfing and AirBnb. Contemporarary Research, 9(1), pp.8590. http://dx.doi.org/10.7903/cmr.11116.

Yin, R.K., 1994. Case Study Research - Design and Methods. $2^{\text {nd }}$ Ed. London: Sage Publications.

\section{ABOUT THE AUTHOR}

Anette Oxenswardh - PhD. Senior Lecturer, Uppsala University/Campus Gotland, Department of Engineering Sciences, Quality Sciences, Sweden. Email: anette.oxenswardh@angstrom.uu.se. Author's ORCID: orcid.org/00000001-9690-2620.

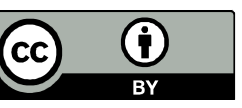

(C) 2018 by the authors. Submitted for possible open access publication under the terms and conditions of the Creative Commons Attribution (CC-BY) license (http://creativecommons.org/licenses/by/4.0/). 